\title{
Erratum to: Effect of land use on pollution status and risk of fish endocrine disruption in small farmland ponds
}

\author{
Syaghalirwa N. M. Mandiki • Virginie Gillardin • Koen Martens • \\ Dirk Ercken - Els De Roeck - Tom De Bie - Steven Declerck • \\ Luc De Meester - Catherine Brasseur - Edwige Van der Heiden • \\ Marie-Louise Scippo $\cdot$ Patrick Kestemont
}

Published online: 27 September 2013

(C) Springer Science+Business Media Dordrecht 2013

\section{Erratum to: Hydrobiologia \\ DOI 10.1007/s10750-013-1641-3}

Due to an unfortunate turn of events, the penultimate author's surname appeared incorrectly in the original publication and should have read Scippo. The correct representation of the authors' names is listed above and should be treated as definitive by the reader.

The online version of the original article can be found under doi:10.1007/s10750-013-1641-3.

S. N. M. Mandiki $(\bowtie) \cdot$ V. Gillardin · P. Kestemont University of Namur, URBE-NARILIS, 61 Rue de Bruxelles, 5000 Namur, Belgium

e-mail: Robert.Mandiki@fundp.ac.be

K. Martens · D. Ercken · E. De Roeck

Royal Belgian Institute of Natural Sciences, Vautierstraat

29, 1000 Brussels, Belgium

T. De Bie $\cdot$ S. Declerck $\cdot$ L. De Meester

32, 3000 Leuven, Belgium

C. Brasseur

Laboratory of Mass Spectrometry, University of Liège, CART, Allée de la Chimie, 6, Bât B6, Sart Tilaman, 4000 Liege, Belgium

E. Van der Heiden · M.-L. Scippo Laboratory of Food Analysis, University of Liège, CART, Bld de Colonster, 20, Bât B43b, Sart Tilman, 4000 Liege, Belgium 